\title{
Chronic Hepatitis in West and East
}

\author{
Limas Kupcinskas \\ Department of Gastroenterology, Kaunas University of Medicine, Kaunas, Lithuania
}

\author{
Key Words \\ Chronic hepatitis - Hepatitis B virus - Hepatitis C virus • \\ Cirrhosis $\cdot$ Hepatocellular carcinoma
}

\begin{abstract}
The main etiologies of chronic hepatitis $(\mathrm{CH})$ worldwide are viral $\mathrm{B}$ and $\mathrm{C}$ infections. Progression of $\mathrm{CH}$ to end-stage liver disease has a significant impact on mortality and need for liver transplantation worldwide. This review will focus on differences in etiology, prevalence, clinical outcomes of $\mathrm{CH}$ and impact on public health issues between developed Western and developing Eastern countries. Despite achievements in treatment and prevention of viral hepatitis in Western countries, processes of globalization contribute to further spread of the infections. Further efforts towards the elimination of hepatic $B$ virus transmission throughout implementation of vaccination programs and primary prevention of hepatitis $C$ infection are still of high importance, especially in developing world.

Copyright $\odot 2007$ S. Karger AG, Basel
\end{abstract}

\section{Introduction}

The term chronic hepatitis $(\mathrm{CH})$ means active, ongoing necroinflammatory disease of the liver persisting for more than 6 months that is detectable by biochemical and histological means [1-3]. Progression of $\mathrm{CH}$ to end-stage liver disease has a significant impact on mortality and need for liver transplantation worldwide [4]. This review will focus on differences in etiology, prevalence, clinical outcomes and impact on public health issues of $\mathrm{CH}$ between Western and Eastern countries.

\section{Classification}

The first classification (1968) of CH distinguished cirrhotic and non-cirrhotic stages, and classified the disease according to the histological degree of disease activity into chronic persistent and chronic aggressive varieties [2]. The discovery of viral etiologies for $\mathrm{CH}$ substantiate a development of a new classification (1994), which included primary classification according to etiology, determination of disease severity, and stage of progression [3].

\section{Causes}

The most common cause of $\mathrm{CH}$ is viral infections of the liver (table 1). Other causes include autoimmune, drug-induced hepatitis, Wilson's disease, $\alpha_{1}$-antitrypsin deficiency and cryptogenic hepatitis. $\mathrm{CH}$ is also occasionally noted in conjunction with chronic alcohol abuse; however, current classification does not include alcoholic steatohepatitis, the same as non-alcoholic steatohepatitis, into the $\mathrm{CH}$ category due to different histology $[1,3]$.

\section{KARGER \\ Fax +4161306 1234 \\ E-Mail karger@karger.ch}

www.karger.com
(C) 2007 S. Karger AG, Basel

0257-2753/07/0253-0274\$23.50/0

Accessible online at:

www.karger.com/ddi
Limas Kupcinskas

Department of Gastroenterology, Kaunas University of Medicine Mickeviciaus Str. 9

LT-44307 Kaunas (Lithuania)

Tel. +370 68640 575, Fax +370 37326 508, E-Mail limas.kupcinskas@kmuk.lt 
Table 1. Causes of chronic hepatitis

\begin{tabular}{l}
\hline Etiology \\
\hline Viral hepatitis \\
Hepatitis B virus \\
Hepatitis C virus \\
Hepatitis D virus \\
Autoimmune hepatitis \\
Drug-induced hepatitis \\
Rare diseases \\
Wilson's disease \\
$\alpha_{1}$-Antitrypsin deficiency \\
Cryptogenic hepatitis \\
\hline
\end{tabular}

\section{Viral Hepatitis}

Hepatitis $\mathrm{C}$ virus (HCV) has been recognized as a major cause of chronic liver disease. In industrialized nations, low HCV seroprevalence rates have been reported $(0.6 \%$ in Germany, $0.8 \%$ in Canada, $1.1 \%$ in France, and $1.8 \%$ in USA) in comparison to Asian countries (2.1\% in Indonesia, 3.2\% in China, and 2.4-6.5\% in Pakistan) [5]. Six major genotypes of HCV have been identified [6]. In USA and Europe, genotype 1 is most prevalent (60-70\%), while genotypes 2 and 3 are less common. In Eastern countries, genotype 3 is most common in India and the Far East, genotype 4 - in the Middle East, and genotype 6 - in Hong Kong and Vietnam. Genotype identification is clinically important because genotypes 1 and 4 are more resistant than genotypes 2 and 3 to the current standard interferon-based therapies.

In Western countries, hepatitis B virus (HBV) infection is relatively rare (prevalence rate $<1 \%$ ) and acquired primarily in adulthood, whereas the chronic HBV infection becomes an endemic in the Asia-Pacific region (prevalence rate $>8 \%$ ), causing hazardous public health problems [7]. Most infections in Asia occur from infected mother to child, and from reuse of unsterilized needles and syringes. HBV can be classified into eight genotypes [8]. Genotype A is mainly prevalent in Europe, North America, India, and Africa, while genotypes $\mathrm{B}$ and $\mathrm{C}$ are found in Asia, and genotype D is more common in Southern Europe, the Middle East, and India. Cirrhosis and hepatocelullar carcinoma (HCC) are more frequent in carriers of genotype C than B [8]. However, despite increasing data on pathogenic differences among genotypes, the response to current antiviral treatments is only partly clarified, therefore routine HBV genotype testing in clinical practice is not recommended this time.
Hepatitis D virus (HDV) is a rare cause of $\mathrm{CH}$. HDV is dependent on the hepatitis B virus and can only superinfect (in 5\%) individuals with HBV infection [7]. Serologic studies have shown that HDV is found worldwide; however, the infection is endemic particularly in the Mediterranean area. Three major HDV genotypes are identified; genotype 1 is prevalent worldwide and genotype 2 in East Asia [9]. In the last decade, HDV infection has very rarely been encountered in the USA and Europe, and has markedly decreased also in some Asia countries, where HBV vaccination was implemented [10].

\section{Autoimune Hepatitis}

Originally described in Northern Europeans and Northern Americans, autoimmune hepatitis (AIH) has a worldwide distribution. It was considered that $\mathrm{AIH}$ is a rare disease in Asian countries compared to the West; however, a recent study from Taiwan concluded that the incidence of AIH is much higher than previously presumed [11]. In Taiwan, as in Western countries, AIH type 1 is the predominant type of disease.

\section{Drug-Induced Hepatitis}

More than 1,000 drugs have been associated with idiosyncratic hepatotoxicity. Drugs like nitrofurantoin, minocycline and methyldopa have been described as being the cause of so-called 'drug-induced chronic active hepatitis' [12]. However, in the wide spectrum of druginduced liver injury from fulminant liver failure to liver tumors, $\mathrm{CH}$ is a rare type of liver damage.

\section{Rare Diseases}

$\alpha 1$-Antitrypsin deficiency is a condition mainly affecting Caucasians, with only anecdotically cases in other ethnicities [13]. Contrarily, Wilson's disease is a genetic disorder that is found worldwide. Among more than 300 Wilson's gene distinct mutations, H1069Q missense mutation is the most common in Europe, and R778L in Japan [14].

\section{Outcomes}

Globally, $57 \%$ of cirrhosis and $78 \%$ of HCC cases were attributable to either chronic HBV or HCV infection [4]. In the USA, only 7 and $27 \%$ cases of cirrhosis are attributed to $B$ and $C$ virus, contrarily to China (66 and $32 \%$, respectively). Most of HCC cases both in the USA and China are caused by HBV and HCV, however with opposite proportions (20 and 51\% in the USA, and 72 and $22 \%$ 
in China) [4]. Implementation of antiviral therapy can decrease the risk of liver decompensation and HCC for those already infected; however, in less-developed Eastern countries the opportunities for modern treatment might be limited. Starting in the 1990s, many Western and a few less developed countries implemented universal hepatitis B immunization and experienced measurable reductions in HBV-related diseases [10]. Primary prevention of hepatitis $\mathrm{C}$ infection should be directed on safer blood supply, safe injection practices in the developing world and decreasing of the number of people who start injection drug use worldwide [5].

\section{Conclusions}

In conclusion, the main etiologies of $\mathrm{CH}$ worldwide are viral $\mathrm{B}$ and $\mathrm{C}$ infections. There exist significant differences in the prevalence of viral $\mathrm{CH}$ and divergence in outcomes of the disease between Western and Eastern countries; however, processes of globalization contribute to further spread of the infections. Further efforts towards the elimination of hepatic B virus transmission throughout implementation of vaccination programs and primary prevention of hepatitis $\mathrm{C}$ infection are still of high importance, especially in the developing world.

\section{References}

1 Ishak KG: Pathologic features of chronic hepatitis. Am J Clin Pathol 2000;13:40-55.

- 2 De Groote J, Desmet VJ, Gedigk P, Korb G, Popper H, Poulsen H, Scheuer PJ, Schmid M, Thaler H, Uehlinger E: A classification of chronic hepatitis. Lancet 1968;2:626-628.

3 Terminology of chronic hepatitis, hepatic allograft rejection, and nodular lesions of the liver: Summary of recommendations developed by an international working party, supported by the WGG, Los Angeles 1994. Am J Gastroenterol 1994;89(suppl 8):S177-S181.

4 Perz JF, Armstrong GL, Farrington LA, Hutin YJ, Bell BP: The contributions of hepatitis $B$ virus and hepatitis $C$ virus infections to cirrhosis and primary liver cancer worldwide. J Hepatol 2006;45:529-538.
5 Shepard CW, Finelli L, Alter MJ: Global epidemiology of hepatitis $\mathrm{C}$ virus infection. Lancet Infect Dis 2005;5:558-567.

-6 Simmonds P, Bukh J, Combet C, et al: Consensus proposals for a unified system of nomenclature of hepatitis $\mathrm{C}$ virus genotypes. Hepatology 2005;42:962-973.

7 Lavanchy D: Worldwide epidemiology of $\mathrm{HBV}$ infection, disease burden, and vaccine prevention. J Clin Virol 2005;34(suppl 1):S1S3.

8 Liu CJ, Kao JH, Chen DS: Therapeutic implications of hepatitis B virus genotypes. Liver Int 2005;25:1097-1107.

\9 Casey JL, Brown TL, Colan EJ, Wignall FS, Gerin JL: A genotype of hepatitis D virus that occurs in northern South America. Proc Natl Acad Sci USA 1993;90:9016-9020.
10 Chen DS: Viral hepatitis: from A to E, and beyond? J Formos Med Assoc 2003; 102:671679.

11 Koay LB, Lin CY, Tsai SL, Lee C, Lin CN, Sheu MJ, Kuo HT, Sun CS: Type 1 autoimmune hepatitis in Taiwan: diagnosis using the revised criteria of the International $\mathrm{Au}$ toimmune Hepatitis Group. Dig Dis Sci 2006;51:1978-1984.

12 Goodman ZD: Drug hepatotoxicity. Clin Liver Dis 2002;6:381-397.

13 De Serres FJ: Worldwide racial and ethnic distribution of $\alpha_{1}$-antitrypsin deficiency: summary of an analysis of published genetic epidemiologic surveys. Chest 2002;122: 1818-1829.

14 Chu NS, Hung TP: Geographic variations in Wilson's disease. J Neurol Sci 1993;117:1-7. 